\title{
Verse texts in the Latin inscriptions of Estonian ecclesiastical space: meter, rhythm and prosody
}

\author{
Anni Arukask, Kaidi Kriisa, Maria-Kristiina Lotman, Tuuli Triin \\ Truusalu, Martin Uudevald, Kristi Viiding*
}

\begin{abstract}
In 2014, the project CEILE (Corpus Electronicum Inscriptionum Latinarum Estoniae, EKKM 14-364) was launched within the framework of the program "Estonian language and cultural memory", in order to systematically map and study the Latin inscriptions created before 1918 and stored in Estonian Lutheran and Catholic churches. As of 2018, the database contains more than 300 inscriptions. Although the proportion of verse texts is not high (13 entries), the fact that the material (totalling 175 verses) has survived almost completely, part of them in situ and partly in transcriptions, and contains several lengthier texts, allows us to make certain generalizations about their metrical and prosodic structure. In this paper, we will give an overview of the chronology and sites of inscriptions and describe the metrical, rhythmical and prosodic structure of the verse texts, addressing also the conjectural role of meter and prosody in our work. We will also dwell on the metrical and prosodic correctness of the texts and will take a separate look at the prosodic licences and errors which occur in the verse texts of the corpus.
\end{abstract}

Keywords: inscriptions; hexameter; rhythm; meter; prosody; churches in Estonia; Latin

\section{Electronic corpus of Latin inscriptions of Estonia (CEILE)}

Thus far, the early non-Estonian versification culture in the Estonian area has been studied only on the basis of printed and manuscript poetry texts (see, for instance, Lepajõe 1994a and 1994b; Kuuse 2014; Viiding et al. 2007; Ross 2018). However, from the middle of the 16th century at the latest, verse texts

\footnotetext{
* Authors' addresses: Anni Arukask, Department of Classical Studies, University of Tartu, Lossi 3, 51003 Tartu, Estonia. E-mail: anni.arukask@gmail.com; Kaidi Kriisa, Department of Classical Studies, University of Tartu, Lossi 3, 51003 Tartu, Estonia. E-mail: kaidi.kriisa@ut.ee; Maria-Kristiina Lotman, Department of Classical Studies, University of Tartu, Lossi 3, 51003 Tartu, Estonia. E-mail: maria.lotman@ut.ee; Tuuli Triin Truusalu, Department of Classical Studies, University of Tartu, Lossi 3, 51003 Tartu, Estonia. E-mail: tullax@ut.ee; Martin Uudevald, Department of Classical Studies, University of Tartu, Lossi 3, 51003 Tartu, Estonia. E-mail: martin.uudevald@ut.ee; Kristi Viiding, Under and Tuglas Literature Centre of the Estonian Academy of Sciences, Roosikrantsi 6, 10119, Tallinn, Estonia. E-mail: kristi.viiding@gmail.com.
} 
for visual reception have also been exhibited in the Estonian public space, first of all, as inscriptions on buildings of different functions, artworks and objects of utility (see also Viiding, Lotman et al. 2015; Lotman, Mänd, Viiding 2017).

In the Estonian area, for many centuries the church was one of the spaces most open to dissemination of verse texts. Being open to different social strata, in addition to religiousness, the church with its services and practices has fostered musical culture, reading, listening and memorizing skills, artistic taste and knowledge. The role of the church in fostering verse culture is significant as well. For now, first of all, the creation and dissemination of Estonian church songs during the Early Modern period has gained attention (e.g. Ross 2016, 2018), while from the aspect of verse technique, verse texts from the objects, artworks and buildings of ecclesiastical space have not yet been systematically studied.

In our paper, we will focus on verse texts which have been gathered from Lutheran and Catholic churches or former monasteries in the Estonian area, including both the inscriptions which are still to be found in these buildings and the lost inscriptions, in which case we rely on archival and literary sources. This material forms a small part of the entries in the database "Corpus Electronicum Inscriptionum Latinarum Estoniae" (The electronic corpus of Latin inscriptions of Estonia) built in the framework of the joint project of the Department of Classics in the University of Tartu, Under and Tuglas Literature Centre of the Estonian Academy of Sciences, and the Institute of History in Tallinn University. The database, the compilation of which is still in progress, will use the methods and presentation developed in the framework of the CEILE project and will be made available online by the end of 2018. Since most of the material from the Estonian churches, that is, more than 300 entries have already been collected, the gathered material allows to map an approximate incidence of verse texts and their placement in the ecclesiastical space; types of objects, on which the verse texts were used; the chronology of Latin verse texts and subgenres from the aspect of their content; the metrics, rhythmics and prosody of the verse texts.

In this paper, we will give an overview of the chronology and sites of inscriptions and describe the metrical and prosodic structure of the verse texts. We have limited the material for rhythmic analysis to verse texts written in classical quantitative meters, leaving aside church songs and hymns, but also iambic verses, the sample of which is too small for a statistical analysis. We will study the structure of these texts, using as comparison the available data of classical meters, both from the antiquity (Virgil and Ovid) and from printed Early Modern Neo-Latin poems of the Estonian area. We will touch upon the ancient and humanist formulative examples only to the extent they might have influenced the principles of versification. However, it is not possible to dwell 
on the comparison between verse inscriptions in Latin and in other languages in this paper, yet the CEILE versification will be compared to that of the Latin inscriptions collected in Finland and Germany.

\section{Latin verse texts in the CEILE}

Our database contains thirteen Latin verse inscriptions, altogether 175 verse lines, which have been preserved in situ or were recovered from archives as transcriptions and belong to the period of 1549-1738. It is a very small part of all Latin inscriptions from local churches: the preliminary estimation is $4 \%{ }^{1}$ The earliest known poems from 1550 s-1560s point to the fact that in the period before the Reformation, the ecclesiastical space of this area was not yet open to poetic self-expression in ancient meters in the Latin language, although the rise of humanism at the end of the 15th century and in the 16th century might have favored it. As we can see from the following table, the creation of verse texts is divided rather evenly between the second half of the 16 th century and the entire 17th century. The only example from the 18 th century is quite exceptional.

Table 1. Verse inscriptions by addressee and location

\begin{tabular}{|l|l|l|l|l|}
\hline & Year & Addressee & Original place & $\begin{array}{l}\text { Material, function and } \\
\text { technique }\end{array}$ \\
\hline 1. & $1549^{*}$ & Heinrich Bock & $\begin{array}{l}\text { Tallinn St. } \\
\text { Nicholas }\end{array}$ & Wooden epitaph painting \\
\hline 2. & 1561 & Johann Hobbing & $\begin{array}{l}\text { Tallinn St. } \\
\text { Nicholas }\end{array}$ & Wooden epitaph painting \\
\hline 3. & $1565^{*}$ & Johann Hauwers & $\begin{array}{l}\text { Tallinn St. } \\
\text { Nicholas }\end{array}$ & Wooden epitaph painting \\
\hline 4. & 1591 & $\begin{array}{l}\text { Pontus de La Gardie } \\
\text { \& Sophia Gyllenhielm }\end{array}$ & $\begin{array}{l}\text { Tallinn } \\
\text { Cathedral }\end{array}$ & $\begin{array}{l}\text { Stone sarcophagus and } \\
\text { epitaph }\end{array}$ \\
\hline 5. & 1598 & Retable & $\begin{array}{l}\text { Lääne-Nigula } \\
\text { (Pönal) }\end{array}$ & $\begin{array}{l}\text { Old retable, painting on } \\
\text { wood }\end{array}$ \\
\hline 6. & $1603^{*}$ & Bernhard Herbers & $\begin{array}{l}\text { Tallinn St. } \\
\text { Nicholas }\end{array}$ & Tombstone, epitaph \\
\hline
\end{tabular}

1 The verse epitaphs which are preserved only in manuscripts with no reference to their implementation in church (e.g. the poem by Johannes Lohmüller for the Bishop of Ösel-Wiek Johannes Orgas 1515), are not included in the present article. For such texts, see Viiding 2019. 


\begin{tabular}{|l|l|l|l|l|}
\hline & Year & Addressee & Original place & $\begin{array}{l}\text { Material, function and } \\
\text { technique }\end{array}$ \\
\hline 7. & 1630 & Martin Winter & $\begin{array}{l}\text { Noarootsi } \\
\text { (Nukkö) }\end{array}$ & Stone epitaph \\
\hline 8. & $1632^{*}$ & Johann Knopius & $\begin{array}{l}\text { Tallinn } \\
\text { St. Nicholas }\end{array}$ & Stone epitaph \\
\hline 9. & 1634 & Thomas von Ramm & $\begin{array}{l}\text { Tallinn } \\
\text { Cathedral }\end{array}$ & Stone sarcophagus \\
\hline 10. & $1662^{\star}$ & Heinrich Arninck & $\begin{array}{l}\text { Tallinn } \\
\text { St. Nicholas }\end{array}$ & Wooden epitaph painting \\
\hline 11. & 1681 & Heinrich Göseken & $\begin{array}{l}\text { Kullamaa } \\
\text { (Goldenbeck) }\end{array}$ & Wooden epitaph painting \\
\hline 12. & 1685 & Church Bell Salvator & $\begin{array}{l}\text { Tallinn } \\
\text { Cathedral }\end{array}$ & $\begin{array}{l}\text { Bronze bell, } \\
\text { metal cast }\end{array}$ \\
\hline 13. & 1738 & Chalice & $\begin{array}{l}\text { Vastseliina } \\
\text { (Neuhausen) }\end{array}$ & $\begin{array}{l}\text { Silver, } \\
\text { metal cast }\end{array}$ \\
\hline
\end{tabular}

* The inscriptions which are not extant today.

It is a clear tendency that the spread of Latin inscriptions started from town churches and first of all from Tallinn, North Estonia, which remained Lutheran in the Early Modern period throughout the entire period of Swedish rule. Only as late as the end of the 16th century did verse inscriptions reach a few churches in the rural area, especially in Western Estonia (Lääne-Nigula, Noarootsi, Kullamaa). The only known verse inscription from South Estonia is an 18th-century silver chalice, but in all probability, it can be explained by the more intense military action in this region, as well as by the events of the Counter-Reformation from 1561 until ca 1629.

As regards the content of the verse inscriptions, we are mostly dealing with laments about a personal addressee, who is male. The poems recall the details of the deceased life, praise his virtues, including piety, refer to his new, heavenly joys and call on the churchgoers to think of human mortality. Only the verses on the retable of the Lääne-Nigula comment on the depicted composition, underlining the aspect of the artist's choice. The latest verse inscriptions at the turn of the 17th and 18th centuries can be found on other church items, describing in the personified form, in the first person, the function and history of an item, thus forming a narrower subtype of epigraphic writings. 


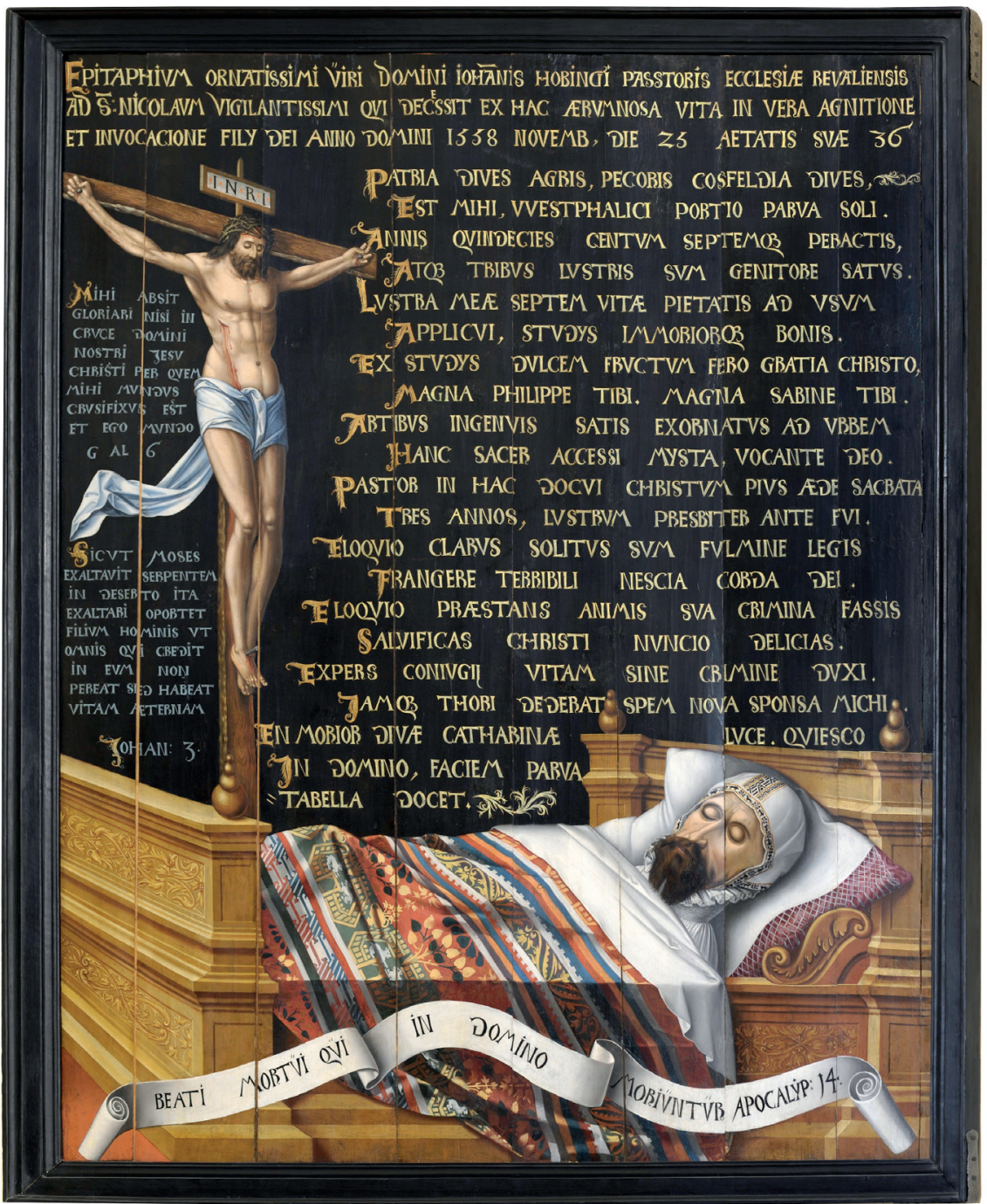

Figure 1. The oldest preserved example of quantitative elegiac distichs in Estonian churches - on the epitaph painting for Johann Hobbing at St. Nicholas' Church, Tallinn (photo by Stanislav Stepashko)

Addressees of half of the Latin inscriptions are local pastors and clerical persons (Bock, Hobbing, Winter, Knopius, Arninck, Göseken), the rest are the local aldermen, for example, a syndic (Herbers) and mayor (Hauwers) and the representatives of Swedish central rule (von Ramm; De La Gardie). In the case of De La Gardie, his wife Sophie Gyllenhielm is mentioned as an addressee, yet, the verse texts still praise only De La Gardie's life and actions (Figure 2). 


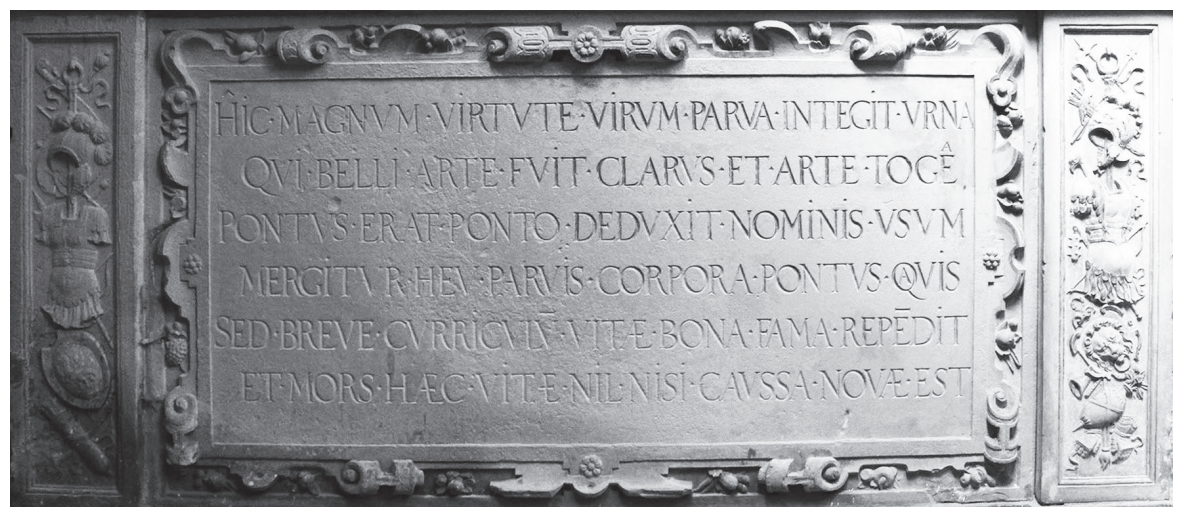

Figure 2. Three elegiac distichs on the footboard of the Sarcophagus of Pontus de La Gardie and his wife Sophia Gyllenhielm at Tallinn Cathedral (photo by Anni Arukask)

Thus, we can say that Latin verse inscriptions are connected with the spiritual, secular and intellectual elite of the society. Urban citizens, including the otherwise influential body of merchants as well as the representatives of Baltic knighthood, are not connected with the creation of Latin verse inscriptions: in their case, German inscriptions or more formulaic prose inscriptions in Latin are preferred. The author of an inscription is known only in one exceptional case: Timotheus Polus, Professor of poetics in Tallinn Gymnasium, composed a text for the monument to Johannes Knopius. Therefore, we are dealing with a distinct phenomenon of humanist culture in the local ecclesiastical space.

The objects with verse texts and their placement in the ecclesiastical space are in correspondence with the content related to the memorial culture. In most cases, a Latin verse text was carved or embossed on a gravestone or sarcophagus or painted onto wood of an epitaph or retable. Predominantly, they were placed on the floor or walls of a main body of a church. Sarcophagi as bigger objects could also have been placed to chapels (for example, von Ramm's sarcophagus in the St George's chapel in Tallinn Cathedral) or, as an exception, to a chancel (De La Gardie's grave monument in the same church, Johannes Winter's epitaph alongside the altar in the Noarootsi church). In a small country church in Lääne-Nigula, quantitative verses can even be found on the retable. Only the latest Latin verse texts are on other kinds of objects church bell (Figures 3a and $3 \mathrm{~b}$ ) and chalice, cast or inscribed on the metal. 

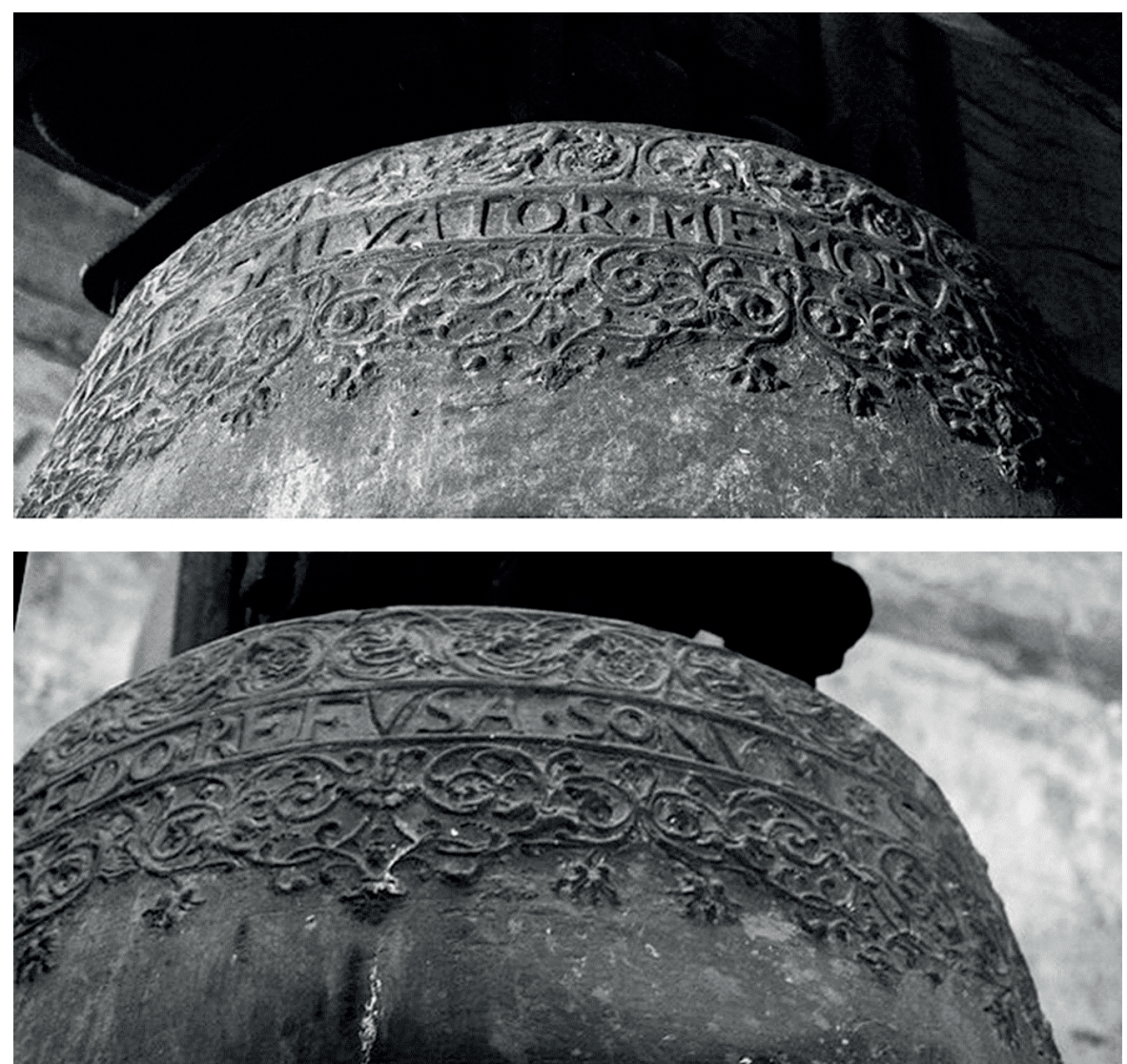

Figure 3a-b. The beginning and the ending of the elegiac distich around the Salvator bell at Tallinn Cathedral (photos by Anni Arukask)

All in all, there were no places in the local Early Modern ecclesiastical space where a Latin verse inscription could not have been written. Yet we can still see a range of certain items, where such inscriptions probably would have been inappropriate - we have no examples of Latin verses in the local chancels or organs.

We can see by the arrangement of all the Latin verse inscriptions on the objects that there was a firm intention to display these as versified texts. In almost all possible cases the verse text is organized line by line, while the pentameters in elegiac distichs are indented to the right under the hexameter (Figures 1 and 2). However, since the textual cartouche is small, sometimes the crafters were forced to find other solutions. Thus, for instance, on Martin Winter's epitaph, both lines of the elegiac distich are divided into two (compare Figure 4). 


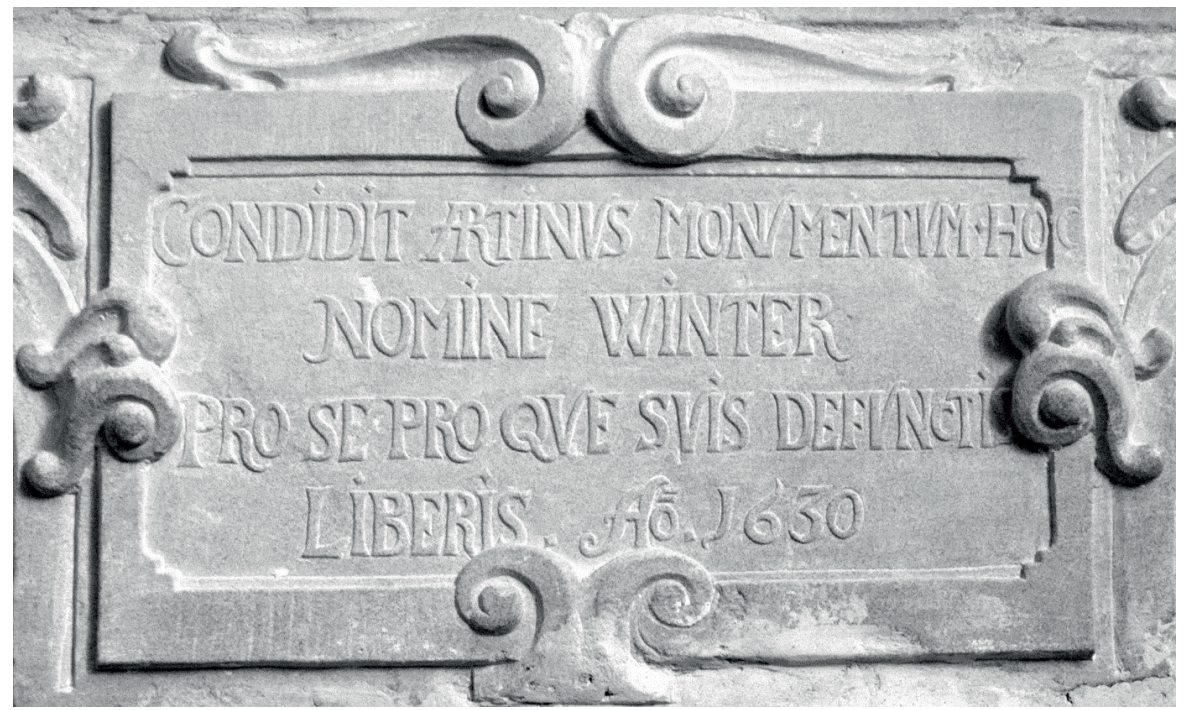

Figure 4. Elegiac distich on the epitaph of Martin Winter at Noarootsi (Nukkö) Church (photo by Martin Uudevald)

In addition, a number of non-traditional ligatures have been used (for example, in the name Martin, the first three initial letters have been depicted as one graph; Monumentum contains the ligatures of $n v$ and me (Figure 5); in the word Defunctis, $c$ is squeezed between other letters as a smaller symbol, while $v$ is carved in an extremely narrow shape (Figure 6) and the letters of line endings can be written even on the frame of a cartouche, for instance, $c$ in the word Hoc.

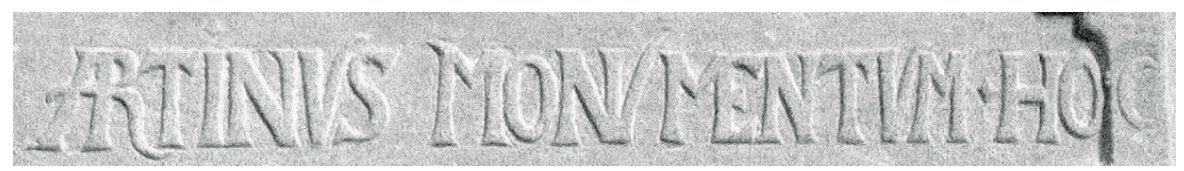

Figure 5. Unusual ligatures in the epitaph of Martin Winter (photo by Martin Uudevald)

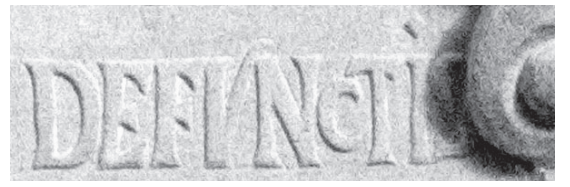

Figure 6. The use of the letter $c$ in the epitaph of Martin Winter (photo by Martin Uudevald) 
On von Ramm's sarcophagus in Tallinn Cathedral, each of the three text cartouches has been too narrow to display hexameters and pentameters as separated verse lines. Here the stonemason has marked the line endings with single or double dots (Figure 7).

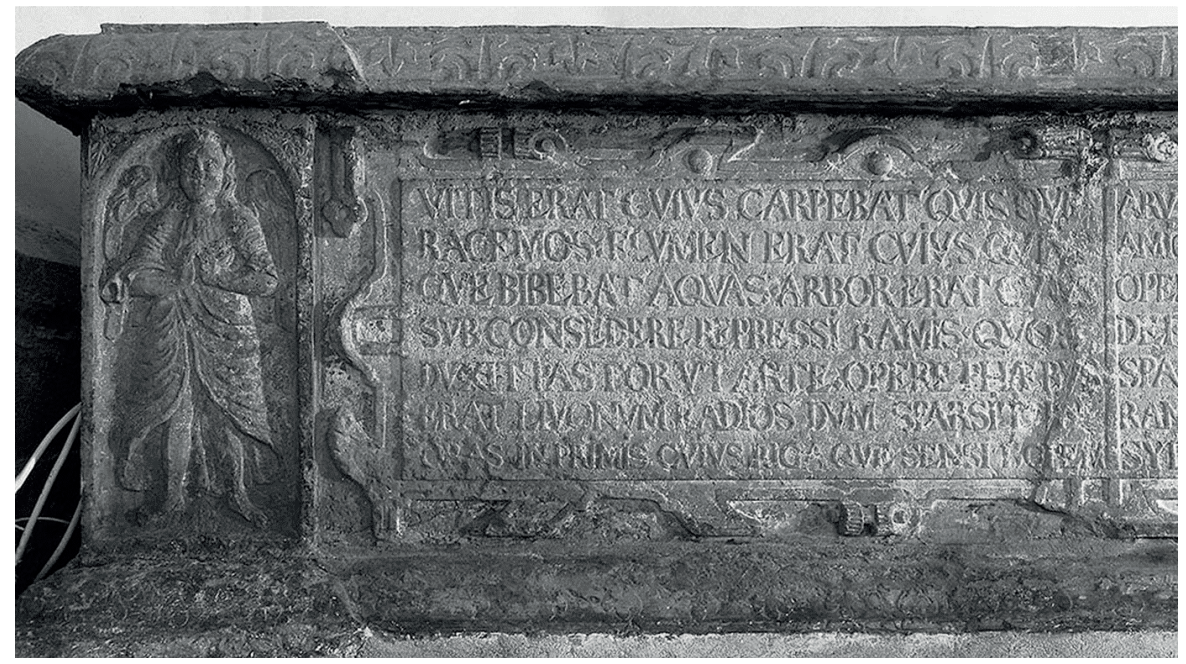

Figure 7. Three elegiac distichs on the right cartouche of the sarcophagus of Thomas von Ramm at Tallinn Cathedral (photo by Peeter Säre)

On the 1738 silver chalice, where the text has been placed as a continuous ribbon around the exterior upper side of the chalice, the verse lines are distinguished with a single slash (Fig. 8).

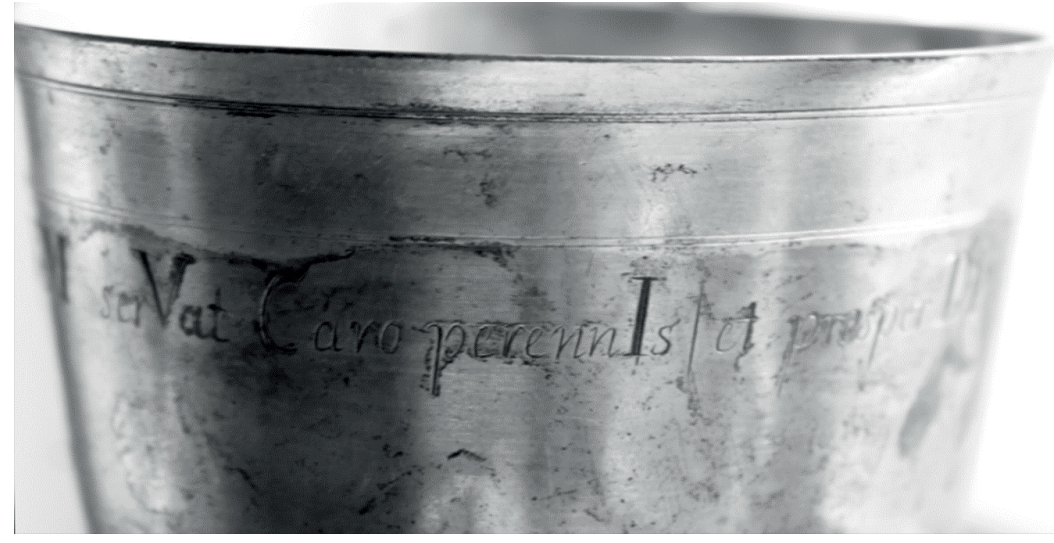

Figure 8. Line break after the word perenn/s marked on a silver chalice form Vastseliina Church, now in the Valga Museum (photo by Anni Arukask) 
The only exception with no clear visual reference to the verse form of the text is the retable of Lääne-Nigula. Here both verses of the elegiac distich are divided into three parts, the three iambs even between five lines, depending on the figural composition of the retable (see Ederberg 1930: 193-199, figures 2 and 7).

\section{Verse meters in CEILE}

In the following table, the list of the most important Latin verse inscriptions is presented. Altogether, it contains 13 inscriptions, mostly in classical meters elegiac distich in most inscriptions, one hexametrical poem and three verses in iambs. In addition to that, just to provide an example, we included a text in this table, which is not in a classical meter, but is founded on syntactic parallelisms and sound repetitions. There are also a number of entries in our database, representing inscriptions which contain quotations from the poetic parts of the Bible. Consequently, as concerns the metrical structure, our material can be roughly divided into two parts: (i) ancient quantitative meters and (ii) verses which are founded on the principles of Hebrew poetics. In this paper, we will focus on the first group of inscriptions.

Table 2. Meters in Latin inscriptions

\begin{tabular}{|r|l|l|l|r|}
\hline & Year & Addressee & Metre & $\begin{array}{r}\text { Number } \\
\text { of verses }\end{array}$ \\
\hline 1. & $1549^{\star}$ & Heinrich Bock & el.dist. & 12 \\
\hline 2. & 1561 & Johann Hobbing & el. dist. & 20 \\
\hline 3. & $1565^{\star}$ & Johann Hauwers & el. dist. & 6 \\
\hline 4. & 1591 & $\begin{array}{l}\text { Pontus de La Gardie \& } \\
\text { Sophia Gyllenhielm }\end{array}$ & el. dist. & 12 \\
\hline 5. & 1598 & - (retable) & el. dist. \& iamb & $2+3$ \\
\hline 6. & $1603^{\star}$ & Bernhard Herbers & el. dist. & 4 \\
\hline 7. & 1630 & Martin Winter & el. dist. & 2 \\
\hline 8. & $1632^{\star}$ & Johann Knopius & syntactic prosody & 63 \\
\hline 9. & 1634 & Thomas von Ramm & el. dist. \& hexameter & $12+7$ \\
\hline 10. & $1662^{\star}$ & Heinrich Arninck & el. dist. & 24 \\
\hline 11. & 1681 & Heinrich Göseken & el. dist. & $3+1^{\star}$ \\
\hline 12. & 1685 & - (Church Bell Salvator) & el. dist. & 2 \\
\hline 13. & 1738 & - (Chalice) & el. dist. & 2 \\
\hline
\end{tabular}


Table 2 reveals that the inscriptions are of rather different lengths: when we leave aside the Bible quotations, which are not included in this table, the shortest are two-line verses, the longest is a composition based on the syntactic prosody. If we drop the latter and calculate the proportions of different classical meters by verse line, we see that more than $90 \%$ of the verses of the 112 meters in classical forms are in elegiac distich (compare Chart 1).

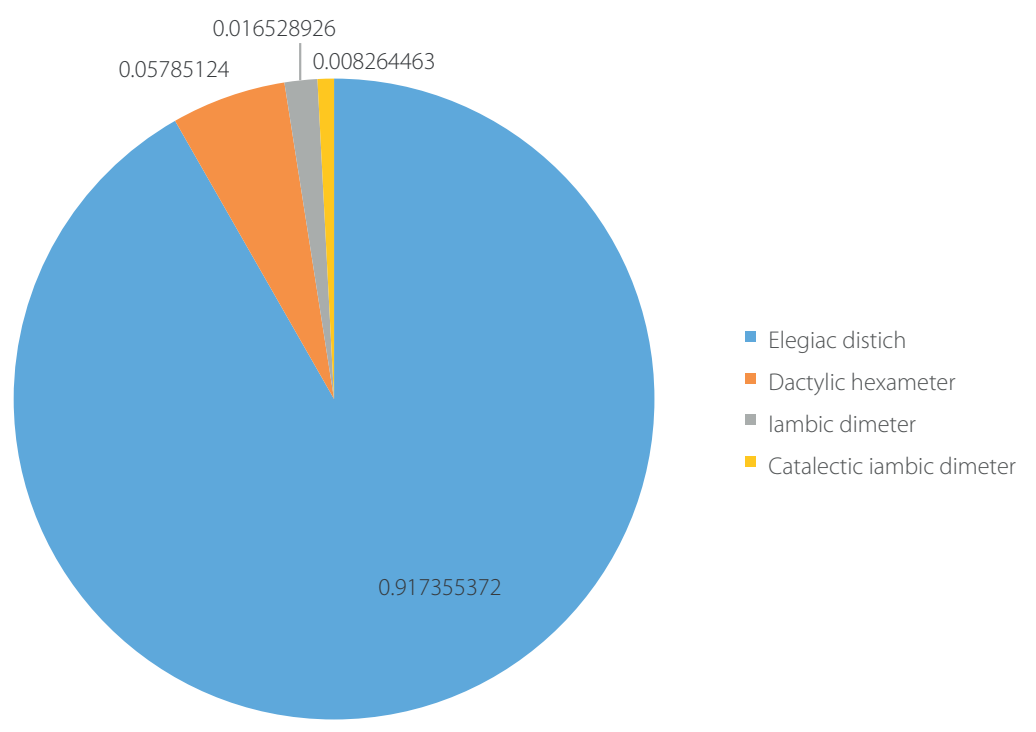

Chart 1. Meters in inscriptions

4. Rhythmical tendencies in the verses in CEILE and their regional context

\subsection{Quantitative-syllabic structure}

In order to describe the rhythmical structure of the inscription verse we will bring out its main statistical regularities and compare these with the corresponding data of both ancient and humanist verse rhythm, as far as these are available to us. Since the sizes of single verse texts are too small for a statistical analysis, we will sum up all the hexameters and pentameters to joint samples. 
This way, we are not able to make generalizations on single poems, yet it gives us a certain picture about the verse technique of the Latin inscriptions in the Estonian area from the 16th to the 18th century.

Table 3 includes data on the rhythmical variations of the first four feet of hexameter, while S signifies spondaic and D dactylic foot. As a comparison, we use De Neubourg's statistical data on Virgil's hexameter (1986: 160) and Annika Kuuse's data of the sample of 300 hexameters by a humanist author Laurentius Ludenius, who was the first professor of rhetoric and poetics from 1634 to 1654 , active in the only academia of this area. In the first column, the data on Latin inscriptions are presented.

Table 3. Rhythmic variations of CEILE hexameter (compared to literary verse)

\begin{tabular}{|l|r|r|r|}
\hline Rhythmic type & CEILE & Virgil Aen. & Ludenius \\
\hline DDDD & $5.2 \%$ & $2.1 \%$ & $3.3 \%$ \\
\hline DDDS & $8.6 \%$ & $6.8 \%$ & $6.3 \%$ \\
\hline DDSD & $6.9 \%$ & $4.7 \%$ & $5.3 \%$ \\
\hline DDSS & $13.8 \%$ & $11.8 \%$ & $8.7 \%$ \\
\hline DSDD & $1.7 \%$ & $3.6 \%$ & $1.3 \%$ \\
\hline DSDS & $6.9 \%$ & $11.2 \%$ & $10.3 \%$ \\
\hline DSSD & $8.6 \%$ & $5.7 \%$ & $8.3 \%$ \\
\hline DSSS & $15.5 \%$ & $14.4 \%$ & $21.0 \%$ \\
\hline SDDS & $5.2 \%$ & $6 \%$ & $4 \%$ \\
\hline SDSD & $5.2 \%$ & $3.8 \%$ & $5.7 \%$ \\
\hline SDSS & $10.3 \%$ & $9.6 \%$ & $7 \%$ \\
\hline SSDS & $6.9 \%$ & $6 \%$ & $5.7 \%$ \\
\hline SSSS & $5.2 \%$ & $7.1 \%$ & $6.3 \%$ \\
\hline Total & $100.0 \%$ & $92.80 \%$ & $93.2 \%$ \\
\hline
\end{tabular}

We can see that the variation of hexameter in CEILE is very similar to the hexameter of Virgil's Aeneid: although the total number of different variations is smaller (the variations of our sample form altogether only about $93 \%$ of variations in Virgil), it is quite expected, since our sample is considerably smaller. At the same time, the proportions of different variations are rather comparable to each other: just like in Virgil, in our material the most common variation is DSSS (CEILE 15.5\%, Virgil 14.4\%), while DDSS takes the second place (a bit higher in CEILE, 13.8\%, almost 12\% in Virgil). SDSS which takes the third place in the material of CEILE, is on the fourth place in Virgil, although the 
incidence is almost the same. In Virgil, the DSDS is ranked as third, the proportion of which is $6.9 \%$ in CEILE. The rest of the data are very close as well.

If we compare these data with Ludenius's indices, we see the same tendencies; however, in Ludenius, the incidence of DSSS is significantly higher than both in Virgil and in CEILE, reaching as high as $21 \%$. On this account, the proportion of DDSS as well as, for example, SSDS is lower, as compared to other data. It is interesting that Ludenius's hexameter is less dynamic than that of the inscriptions of the same period, although he was not constrained with the material conditions (for instance, the stonecutting and its price, the size of the writing area, the layout of the letters, etc).

Furthermore, to put our data in a wider context, we studied the inscriptions gathered from Finland and from an exemplary Northern German Hanseatic city to compare their rhythmic structure with that of the CEILE.

The inscriptions from Finnish churches were collected by the Finnish Latinists and teachers of Classical Languages in 1994-2004, including all inscriptions which were found in interiors and facades of churches, as well as in the church treasuries, independently of their creation time, that is, up till the contemporary inscriptions. The material was gathered also from 880 graveyards surrounding the churches, first of all, from grave monuments and chapels. The ecclesiastical objects stored in museums were not included in the project. All in all, 520 inscriptions were found. Together with Latin inscriptions known from earlier literature, in 2004 a substantial collection of 933 inscriptions was published (Pitkäranta 2004), where the inscriptions were supplemented with Finnish translations and comments about the personalia, events, palaeography, orthography and metrical structure of texts.

The other comparison sample was formed of the inscriptions from Stralsund, the second important Hanseatic town after Lübeck (Magin 2016), keeping in mind the close connections of Estonia and Livonia with the Hanseatic cities around the Baltic Sea. There are 454 known Latin and German inscriptions from Stralsund before 1650. The inscriptions from Stralsund are rather varied, including late medieval Catholic material, texts from the PostReformation period, as well as abundant inscriptions written on Early Modern church inventory and grave monuments. Due to the editorial principles of the series of Deutsche Inschriften, the Stralsund volume contains also inscriptions from secular buildings and organizations. The volume also includes inscriptions which are extant only because of drawings or written descriptions. Each entry is supplemented with a comment on its connections with the history of the city and region. Our sample of Stralsund verses includes only ecclesiastical inscriptions. 
Table 4. Rhythmic variations of CEILE hexameter (compared to other inscriptions)

\begin{tabular}{|l|r|r|r|}
\hline Rhythmic type & CEILE & Finnish & German \\
\hline DDDD & $5.2 \%$ & $5.0 \%$ & $3.8 \%$ \\
\hline DDDS & $8.6 \%$ & $8.1 \%$ & $6.0 \%$ \\
\hline DDSD & $6.9 \%$ & $8.7 \%$ & $5.3 \%$ \\
\hline DDSS & $13.8 \%$ & $8.7 \%$ & $9.8 \%$ \\
\hline DSDD & $1.7 \%$ & $3.7 \%$ & $3.8 \%$ \\
\hline DSDS & $6.9 \%$ & $5.6 \%$ & $10.5 \%$ \\
\hline DSSD & $8.6 \%$ & $8.7 \%$ & $4.5 \%$ \\
\hline DSSS & $15.5 \%$ & $12.4 \%$ & $18.0 \%$ \\
\hline SDDD & $0.0 \%$ & $1.9 \%$ & $1.5 \%$ \\
\hline SDDS & $5.2 \%$ & $3.7 \%$ & $2.3 \%$ \\
\hline SDSD & $5.2 \%$ & $4.3 \%$ & $3.0 \%$ \\
\hline SDSS & $10.3 \%$ & $9.9 \%$ & $9.0 \%$ \\
\hline SSDD & $0.0 \%$ & $0.6 \%$ & $2.3 \%$ \\
\hline SSDS & $6.9 \%$ & $3.1 \%$ & $6.8 \%$ \\
\hline SSSD & $0.0 \%$ & $3.7 \%$ & $3.0 \%$ \\
\hline SSSS & $5.2 \%$ & $11.8 \%$ & $9.8 \%$ \\
\hline Total & $100.0 \%$ & $100.0 \%$ & $99.2 \%$ \\
\hline
\end{tabular}

Here again similar rhythmic tendencies can be seen, but there are two main points of divergence in the data: DDSS, where the index of CEILE is significantly higher, and SSSS, the incidence of which is lower in CEILE. The total number of variations completely coincides with Finnish verse and almost coincides with German verse (German material includes one spondaic verse, not found in Estonian and Finnish inscriptions).

The rhythmic variations of pentameter are shown in the following table, comparing these to the data of ancient pentameter (Platnauer 1951: 37); unfortunately, the corresponding data of the humanist pentameter were unavailable to us. 
Table 5. Rhythmic variations of CEILE pentameter (compared to literary verse)

\begin{tabular}{|l|r|r|r|r|}
\hline Rhytmic type & CEILE & Tibullus & Propertius & Ovid \\
\hline DDDD & $26.5 \%$ & $24 \%$ & $24.1 \%$ & $30.9 \%$ \\
\hline DSDD & $32.7 \%$ & $58.6 \%$ & $43 \%$ & $52.4 \%$ \\
\hline SDDD & $14.3 \%$ & $5.2 \%$ & $16.5 \%$ & $8.3 \%$ \\
\hline SSDD & $24.5 \%$ & $12.2 \%$ & $16.4 \%$ & $8.4 \%$ \\
\hline SDSD & $2.0 \%$ & 0 & 0 & 0 \\
\hline
\end{tabular}

The data of CEILE pentameter do not follow the rhythmic profile of any ancient author. As compared to classical authors, in CEILE pentameter, the distribution of different variations is a bit more even: DSDD stands out, but it is not that prevalent as, for instance, in Ovid and especially Tibullus. The proportion of SDDD is not as low as in Ovid and Tibullus, although, just like in ancient poets, it is also the most infrequent variation. We see also one irregular verse, where a contraction takes place in the first foot of the second half-verse: such liberty is not allowed in classical poets.

Compare:

PRO SE PROQVE SVIS DEFVNCTIS LIBERIS (Figure 4)

Table 6. Rhythmic variations of CEILE pentameter (compared to other inscriptions)

\begin{tabular}{|l|r|r|r|}
\hline Rhythmic type & CEILE & Finnish & German \\
\hline DDDD & $26.5 \%$ & $25.0 \%$ & $16.7 \%$ \\
\hline DSDD & $32.7 \%$ & $30.2 \%$ & $39.8 \%$ \\
\hline DSSD & $0.0 \%$ & $0.0 \%$ & $0.9 \%$ \\
\hline SDDD & $14.3 \%$ & $27.6 \%$ & $15.7 \%$ \\
\hline SDSD & $2.0 \%$ & $0.0 \%$ & $0.0 \%$ \\
\hline SSDD & $24.5 \% \%$ & $17.2 \%$ & $26.9 \%$ \\
\hline Total & $100.0 \%$ & $100.0 \%$ & $100.0 \%$ \\
\hline
\end{tabular}

The data show some significant differences in the proportions of variations. Although in all three samples the most common variation is DSDD, the index of German verse is here somewhat higher. Other prevailing patterns are DDDD and SSDD, the first being most common in CEILE, the second in German inscriptions. Finnish inscriptions always follow the metrical rules of the ancient pentameter, while both in CEILE and in German inscriptions there occur variations DSSD and SDSD, which are prohibited in Roman pentameter. 
Now let us return to hexameter and study not the whole verse lines, but the rhythm of verse feet and pay attention to the statistics of spondees in the first four feet.

Table 7. The proportion of spondaic feet in CEILE hexameter (compared to literary verse)

\begin{tabular}{|l|r|r|r|r|r|}
\hline & I & II & III & IV & Average \\
\hline Ennius & $55,6 \%$ & $56,3 \%$ & $61,4 \%$ & $65 \%$ & $59,6 \%$ \\
\hline Virgil & $39 \%$ & $52,6 \%$ & $59,6 \%$ & $72,5 \%$ & $55,9 \%$ \\
\hline Lucanus & $33,4 \%$ & $54,6 \%$ & $56,8 \%$ & $72,5 \%$ & $54,3 \%$ \\
\hline Ovid & $16,8 \%$ & $52,5 \%$ & $58,8 \%$ & $52,7 \%$ & $45,2 \%$ \\
\hline Propertius & $37,7 \%$ & $51,3 \%$ & $62 \%$ & $71,3 \%$ & $55,6 \%$ \\
\hline Tibullus & $23 \%$ & $55,7 \%$ & $60 \%$ & $75,7 \%$ & $53,6 \%$ \\
\hline Martial & $32 \%$ & $53 \%$ & $64,3 \%$ & $60 \%$ & $52,3 \%$ \\
\hline CEILE & $32.8 \%$ & $44.8 \%$ & $65.5 \%$ & $72.4 \%$ & $53.9 \%$ \\
\hline
\end{tabular}

We can see that the rhythmic type of CEILE verse is what has been called a progressive rhythm: with each verse foot, the percentage of spondees is higher. Such rhythm started to evolve distinctly already in Virgil's verse, although the difference between the 2 nd and the $3 \mathrm{rd}$ foot is not that remarkable yet, just like in Lucanus and in Ovid (who, however, shows a significantly low level of spondees in the first foot, while the number of spondees is not that high in the fourth foot). The data of CEILE are the closest to the rhythm of Propertius and Tibullus, but in the second foot, the number of spondees is lower, while in the first foot, Tibullus's verse shows a lower rate of spondees.

Table 8. The proportion of spondaic feet in CEILE hexameter (compared to other inscriptions)

\begin{tabular}{|l|r|r|r|r|r|}
\hline & I & II & III & IV & Average \\
\hline CEILE & $32.8 \%$ & $44.8 \%$ & $65.5 \%$ & $72.4 \%$ & $53.9 \%$ \\
\hline Finnish & $39.1 \%$ & $49.7 \%$ & $59.6 \%$ & $63.4 \%$ & $53.0 \%$ \\
\hline German & $38.3 \%$ & $59.4 \%$ & $63.2 \%$ & $72.9 \%$ & $58.5 \%$ \\
\hline
\end{tabular}

All samples demonstrate a somewhat similar rhythm, with the lowest percentage of spondees in the first foot and the highest in the fourth foot. The steepest progression can be seen in CEILE verse, while in Finnish sample, the difference between the first and the fourth foot is smaller. 


\subsection{Word boundaries}

Next, we will pay attention to the phenomena related to word boundaries. Let us begin with the caesura. In ancient hexameter, the placement of caesura showed very clear regularities. The caesura was not supposed to divide a line into two equal parts, so, the medial caesura was avoided. In Greek hexameter, the so-called trochaic or the feminine caesura in the third foot was preferred, while in Latin hexameter the so-called penthemimeral or masculine caesura in the third foot became absolutely prevailing. Thus, for instance, in Virgil's Aeneid, more than $80 \%$ of the lines contain such a caesura in the third foot.

Let us compare the Virgil's data with the indices of CEILE hexameters (Chart 2):

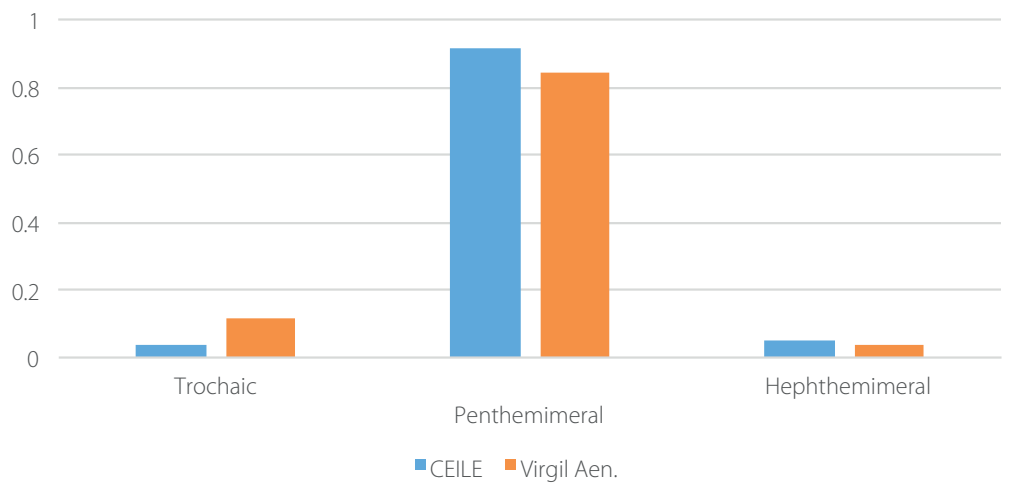

\section{Chart 2. Caesura in CEILE hexameter (compared to Virgil's hexameter)}

We can see that just like normally in ancient Latin hexameter, in CEILE verse too, the masculine or the strong caesura prevails, while in most cases we are dealing with the penthemimeral caesura in the third foot. This tendency is even stronger than in Virgil's hexameter, the data of which are also shown on the chart. This strengthening has occurred mostly on the account of the trochaic caesura, which in our material was very infrequent. There were no lines with medial caesura or without caesura in CEILE material. 


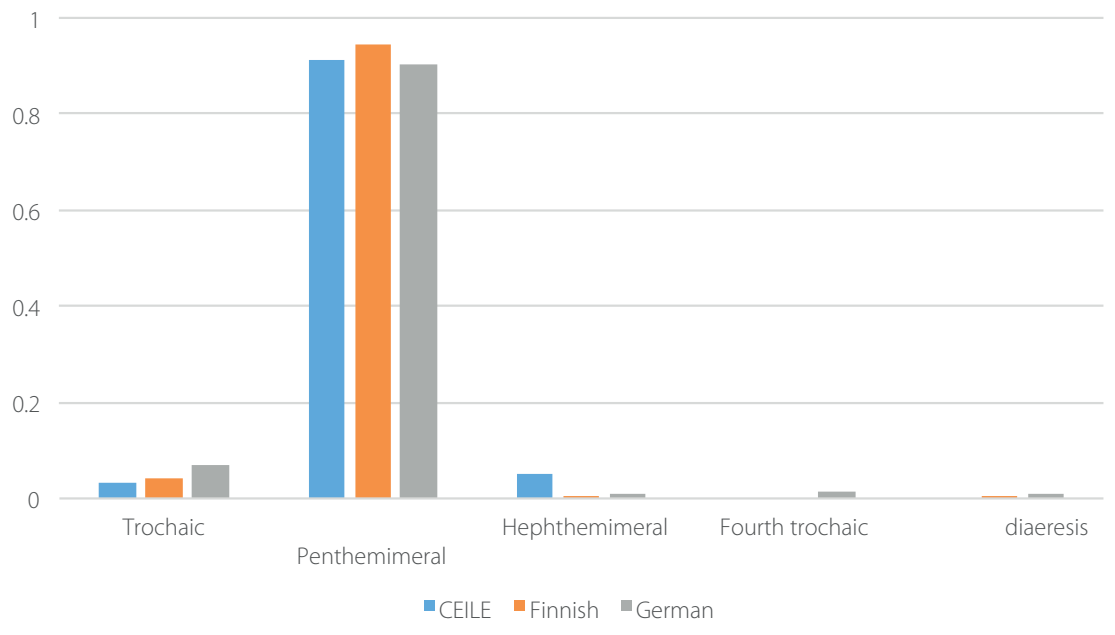

Chart 3. Caesura in CEILE (compared to Finnish and German inscriptions)

There are no significant differences between the three samples: the most common caesura is the penthemimeral break, other types occur mostly as exceptions.

We based our analysis of clausulae on the list of clausula types developed by De Neubourg (De Neubourg 1986: 66-67). The phrases in this list do not signify the actual word pattern (these are not formulas), but they stand for the prosodic word forms, that is, 'conde sepulchro' means a clausula, which contains of one disyllabic word with the accent on the first syllable, and a consequent trisyllabic word with the accent on the second syllable. Thus, 'conde sepulchro' stands for all analogical phrases, like, for example,' aegra trahebant', 'regna uocare,' 'foeda relinquunt', etc. 
Table 9. Clausula types in CEILE hexameter (compared to literary verse)

\begin{tabular}{|l|r|r|r|}
\hline Clausula type & CEILE & Virgil Aen & Ovid Met. \\
\hline abe)untibus heros & $3.4 \%$ & $1.3 \%$ & $2.5 \%$ \\
\hline agno)vitque per umbras & $1.7 \%$ & $0.2 \%$ & $0.1 \%$ \\
\hline armipo)tentis Achilli & $1.7 \%$ & $0.5 \%$ & $0.5 \%$ \\
\hline conde sepulchro & $29.3 \%$ & $16.3 \%$ & $17.2 \%$ \\
\hline condere gentem & $27.6 \%$ & $31.9 \%$ & $31.2 \%$ \\
\hline despec)tare videntur & $1.7 \%$ & $1.2 \%$ & $1.5 \%$ \\
\hline fiet tibi quidnam & $1.7 \%$ & $0 \%$ & $0 \%$ \\
\hline geni)toris ab urbem & $1.7 \%$ & $0.8 \%$ & $1.2 \%$ \\
\hline gente tot annos & $1.7 \%$ & $2.8 \%$ & $3.2 \%$ \\
\hline pe)tamus Acesten & $1.7 \%$ & $0.9 \%$ & $1 \%$ \\
\hline sub)mergere ponto & $25.9 \%$ & $12.3 \%$ & $11.3 \%$ \\
\hline u)nius ob iram & $1.7 \%$ & $2.9 \%$ & $3 \%$ \\
\hline Total & $100.0 \%$ & $71.1 \%$ & $72.7 \%$ \\
\hline
\end{tabular}

It appears that CEILE hexameter is significantly less variable in this aspect than that of the ancient poets: the total range of clausula types in inscriptions corresponds to only slightly less than 70\% of different clausula types in both Virgil and Ovid. The overall tendencies are still roughly the same, although there are certain differences too. For example, the most common clausula type in ancient authors is 'condere gentem' (more than $30 \%$ in both Virgil and Ovid), but in our material it is exceeded by 'conde sepulchro', which forms ca $30 \%$ of all the clausulae, while in Virgil and Ovid it occurs in ca $16-17 \%$ of the cases. In CEILE hexameter the clausula type 'submergere ponto' stands out (23\%), which is less frequent in Virgil and Ovid, occurring in ca 11-12\% of the cases. The incidence of the rest of the clausula types is marginal. One more thing also worth mentioning here is the clausula 'fiet tibi quidnam, which does not occur in ancient classical poets. Compare, however, Horace's verse tibi quidnam acce$\operatorname{det}$ (Sermones 2.2.86), which could have influenced the CEILE clausula. 
Table 10. Clausula types in CEILE hexameter (compared to other inscriptions)

\begin{tabular}{|c|c|c|c|}
\hline Clausula type & CEILE & Finnish & German \\
\hline abe)untibus heros & $3.4 \%$ & $1.9 \%$ & $0.8 \%$ \\
\hline agno)vitque per umbras & $1.7 \%$ & $0.0 \%$ & $0.0 \%$ \\
\hline armipo)tentis Achilli & $1.7 \%$ & $0.0 \%$ & $0.8 \%$ \\
\hline conde sepulchre & $29.3 \%$ & $23.6 \%$ & $10.5 \%$ \\
\hline condere gentem & $27.6 \%$ & $34.8 \%$ & $30.1 \%$ \\
\hline corpore qui se & $0.0 \%$ & $0.0 \%$ & $1.5 \%$ \\
\hline despec)tare videntur & $1.7 \%$ & $0.6 \%$ & $1.5 \%$ \\
\hline Di genuerunt & $0.0 \%$ & $1.2 \%$ & $0.0 \%$ \\
\hline e)repta ruinis & $0.0 \%$ & $6.8 \%$ & $15.0 \%$ \\
\hline facilis quod aquarum & $0.0 \%$ & $0.6 \%$ & $0.0 \%$ \\
\hline fatis genitore & $0.0 \%$ & $1.2 \%$ & $0.0 \%$ \\
\hline fiet tibi quidnam & $1.7 \%$ & $0.0 \%$ & $0.0 \%$ \\
\hline geni)toris ab urbem & $1.7 \%$ & $0.0 \%$ & $0.8 \%$ \\
\hline gente tot annos & $1.7 \%$ & $0.0 \%$ & $4.5 \%$ \\
\hline ge)runt benedicti & $0.0 \%$ & $0.6 \%$ & $0.0 \%$ \\
\hline geni)toris ad urbem & $0.0 \%$ & $0.6 \%$ & $0.0 \%$ \\
\hline haeret an haec sit & $0.0 \%$ & $0.6 \%$ & $0.0 \%$ \\
\hline Idae)is cyparissis & $0.0 \%$ & $0.6 \%$ & $0.0 \%$ \\
\hline Incrementum & $0.0 \%$ & $0.0 \%$ & $0.8 \%$ \\
\hline inreme)abilis undae & $0.0 \%$ & $0.0 \%$ & $0.8 \%$ \\
\hline intrac)tabile bello & $0.0 \%$ & $0.6 \%$ & $0.0 \%$ \\
\hline Lengelmekensis obibat & $0.0 \%$ & $0.6 \%$ & $0.0 \%$ \\
\hline medi)um secat agmen & $0.0 \%$ & $0.6 \%$ & $0.0 \%$ \\
\hline o)rigine Caesar & $0.0 \%$ & $3.1 \%$ & $4.5 \%$ \\
\hline pe)tamus Acesten & $1.7 \%$ & $1.2 \%$ & $1.5 \%$ \\
\hline petr)ast ab ilitur & $0.0 \%$ & $0.6 \%$ & $0.0 \%$ \\
\hline prohi)bemur harenae & $0.0 \%$ & $4.3 \%$ & $2.3 \%$ \\
\hline Quadrupedantum & $0.0 \%$ & $1.2 \%$ & $2.3 \%$ \\
\hline si bona norint & $0.0 \%$ & $1.2 \%$ & $0.8 \%$ \\
\hline sub)mergere ponto & $25.9 \%$ & $10.6 \%$ & $18.8 \%$ \\
\hline $\mathrm{u})$ nius ob iram & $1.7 \%$ & $1.9 \%$ & $3.0 \%$ \\
\hline vi)te bibe potum & $0.0 \%$ & $0.6 \%$ & $0.0 \%$ \\
\hline
\end{tabular}


In all three analyzed samples, the most common clausulaic types are 'conde sepulchro', 'condere gentem' and 'submergere ponto', which in CEILE constituted ca $85 \%$, in Finnish verse ca $70 \%$ and in German verse ca $60 \%$ of all clausulae. Thus, there are some differences in the proportions of these types. While in CEILE, the incidence of 'conde sepulchro' and 'condere gentem' is almost even, in Finnish hexameters, the latter is much more common (23.6\% vs $34.8 \%$ ). In German inscriptions, the difference is even bigger: $10.5 \%$ vs. $30.5 \%$. On the other hand, the type 'erepta ruinis' which does not occur in CEILE inscriptions, is represented in Finnish and especially in German hexameters, where its incidence is as high as $15 \%$ of the cases. In Finnish and German samples we can see a number of nonstandard endings, some even not to be found in Virgilian hexameter (cf. 'Lengelmekensis obibat' in a Finnish inscription).

\section{Metrical and prosodic licences and errors}

Although the CEILE material is mostly prosodically correct, there are also a few mistakes.

For example, a verse found in pastor Göseken's epitaph (Figure 9) is prosodically incorrect:

HANNOVERAE GENITUM PUERUM ME WESTPHALIA TELLUS

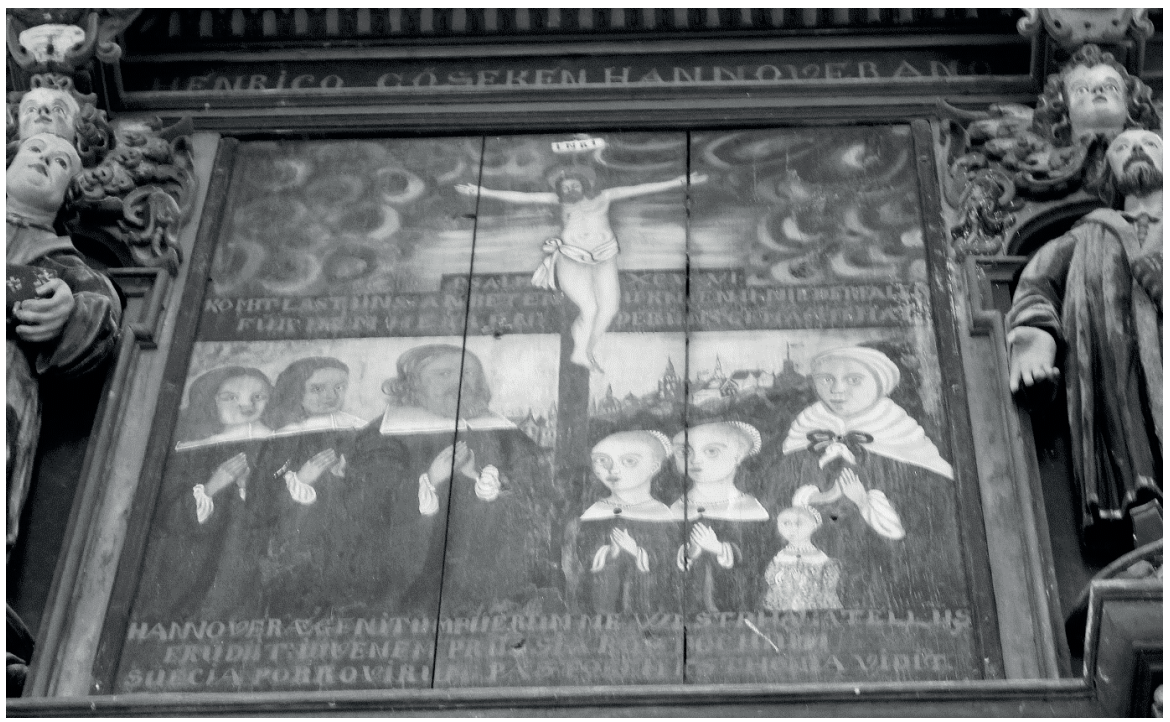

Figure 9. The preserved elegiac distichs at the lower part of the epitaph of Heinrich Göseken at Kullamaa Church (photo by Anni Arukask) 
Here the fourth foot is very problematic. While the last syllable of 'puerum' in the strong position of the fourth foot is correct, the next two syllables (me Westph-), which should fill the pair of shorts in the dactylic foot, are both heavy. Therefore, we are either dealing with the violation of quantitative rules or a flawed use of elision (although in ancient verse, $v$ can sometimes function as a vowel even if it is a glide, for instance, 'silvae' can be a trisyllabic word, words beginning with it are not elided).

The fifth foot in the following line from Heinrich Arninck's epitaph is also dubious:

\section{REDDIDIT AT TERRAE QUOVIS AMICO BEATUM (?)}

If we consider this foot as a dactyl, the last syllable of 'amico' would fill a short position, while it is actually heavy. If we read the first syllable of 'beatum' as synizesis, we would have a spondaic fifth foot, which is also problematic and would be a unique case in our material.

Problematic quantities are also found in pentameter, compare:

TERTIA POST CINERES EDO REFVSA SONVM.

Here we can see, as the last syllable of 'edo' has been subjected to iambic shortening and fills thus a short position (Figure $3 \mathrm{~b}$ ).

It is also interesting to note how the changes in pronunciation have influenced the orthography of inscriptions. For example, we came across the spelling crusifixus pro crucifixus - being an illustration of the pronunciation of the word in late medieval Tallinn. An interesting example is also a word in the following verse from Thomas von Ramm's grave monument (Figures 10-11):

PHŌBUS SES[SAVI]T SPARGERE [L]VMEN ALYS

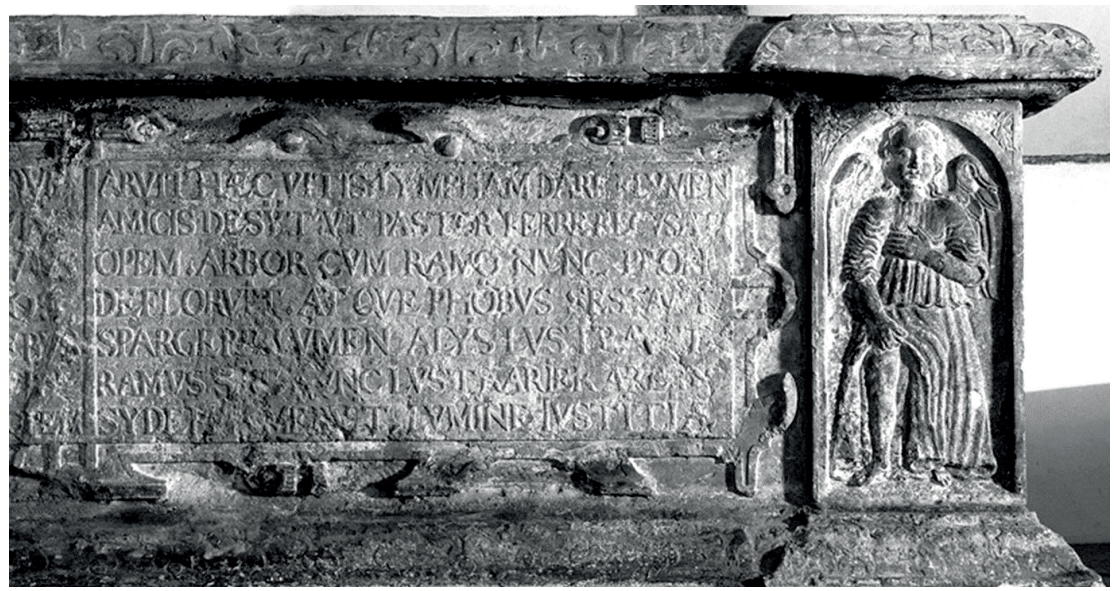

Figure 10. Elegiac distich on the left cartouche of the sarcophagus of Thomas von Ramm at Tallinn Cathedral (photo by Peeter Säre) 
Here cessavit is spelled sessavit, reflecting the pronunciation of the period. Side by side with such modernisms, complete archaisms appear, compare the form of archaic Latin infinitive 'lustrarier' from the same monument, which is obviously used here for metrical reasons:

LVST[RAVIT] RAMVS S[ET NV]NC LVSTRARIER AR[IS]

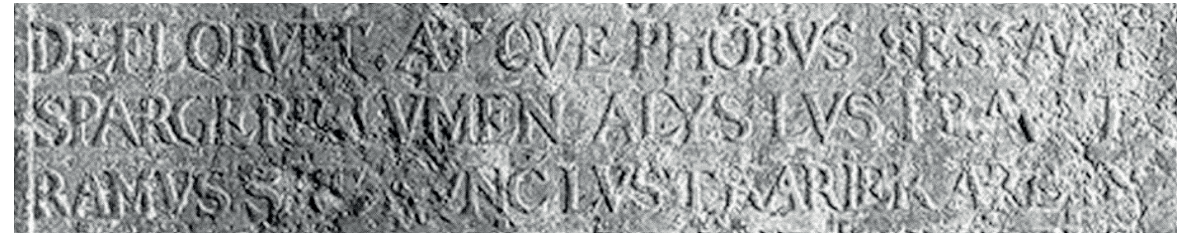

Figure 11. Excerpt of elegiac distich from the left cartouche of the sarcophagus of Thomas von Ramm at Tallinn Cathedral (photo by Peeter Säre)

\section{Summary}

To sum it up, we can say that in spite of a few prosodic and metrical errors the Latin inscriptions from the Estonian area still follow the ancient models and standards quite accurately and that appeared on all the observed levels - metrical, rhythmical and prosodical. Despite being constrained with the material conditions of stonecutting, the rhythmic structure of inscriptions is as dynamic as that of the ancient verse. This evidences that the high humanist poetic culture found expression in the inscriptions of the local ecclesiastical space even before it was pursued on paper or in print.

The comparison with the inscriptions in the same region revealed as well similar rhythmic variability and tendencies with just a few exceptions. The same applies to the structure of word boundaries as well: the placement of caesura as well as clausulaic patterns, where again similar tendencies were revealed. ${ }^{2}$ The analysis of all three samples uncovered a number of prosodic errors and licences as well, reflecting the peculiarities of language use of the era.

2 The writing of this paper was supported by the Estonian Ministry of Education and Research project EKKM14-364 ("Corpus Electronicum Inscriptionum Latinarum Estoniae (CEILE)"), the Estonian Ministry of Education and Research projects IUT28-1 and IUT20-1, and by the European Union through the European Regional Development Fund (Centre of Excellence in Estonian Studies). We would like to thank Dr. Christine Wulf, Göttinger Inschriftenkommission der Akademie der Wissenschaften, for the volume Die Inschriften der Stadt Stralsund (Deutsche Inschriften 102), kindly granted to us. 


\section{References}

De Neubourg. Leo 1986. La base métrique de la localisation des mots dans l'hexamétre latin. (Verhandelingen van de Koninklijke Academie voor Wetenschappen, Letteren en Schone Kunsten van Belgie, Kl. der Letteren 48, Nr. 119). Brussels: AWLSK, Paleis der Academiën.

Ederberg, Eduard 1929. Ein spätmittelalterlicher Flügelaltar aus der Kirche zu Pönal. Beiträge zur Kunde Estlands. Hrsg. von der Estländischen Literärischen Gesellschaft in Reval. Bd. XV, Heft 1. Mai, 194-199.

Kuuse, Annika 2014. The syllabic structure of the hexameters of academic occasional poetry in Tartu in the 17th century. Unpublished conference paper.

Lepajõe, Marju 1994a. Reiner Brockmann: A Neo-Latin or an Estonian Poet? In: Schnur, Rhoda; Moss, Ann (eds.), Acta Conventus Neo-Latini Hafniensis: Congressus Internationalis Studiis Neolatinis Provehendis. (Medieval and Renaissance Texts and Studies 120). Binghamton, N.Y.: Medieval \& Renaissance Texts \& Studies, 597-606.

Lepajõe, Marju 1994b. Latin Poetry in Seventeenth-Century Estonia. Mare Balticum mare nostrum. In: Merisalo, Outi; Sarasti-Wilenius, Raija (eds.), Latin in the countries of the Baltic Sea. Helsinki Colloquium, 16-21 August, 1992 (Annales Academiae Scientiarum Fennicae, ser. B 274). Helsinki: Suomalainen Tiedeakatemia Academia Scientiarum Fennica, 87-96.

Lotman, Maria-Kristiina; Mänd, Anu; Viiding, Kristi 2017. Apprehendite disciplinam... Nõo kirikus leiduvast ladinakeelsest pealiskirjast. In: Randla, Anneli (ed.), Järelevastamine. Kaur Alttoale. Tallinn: Eesti Kunstiakadeemia (Eesti Kunstiakadeemia toimetised 22), 81-96.

Magin, Christine (ed.) 2016. Die Inschriften der Stadt Stralsund (Deutsche Inschriften 102). Wiesbaden: Reichert.

Platnauer, Maurice 1951. Latin Elegiac Verse: A Study of the Metrical Usages of Tibullus, Propertius \& Ovid. Cambridge: Cambridge University Press.

Pitkäranta, Reijo (ed.) 2004. Suomen kirkkojen Latina. EFIL Ecclesiarum Finlandiae Inscriptiones Latinae. Piirtokirjoitukset kirkoissa, kellotapuleissa ja hautausmailla (Suomen kirkkohistoriallisen seuran toimituksia 193). Helsinki: Suomalaisen Kirjallisuuden Seura.

Ross, Kristiina 2016. Kirikulaulu osast eesti keele kirjalikustumisel. In: Lotman, Piret (ed.). Konfessioon ja kirjakultuur. Confession and the Literary Culture (Raamat ja aeg. Libri et memoria 4). Tallinn: Eesti Rahvusraamatukogu, 41-54. 
Ross, Kristiina 2018. Eestikeelne piiblitõlge, kristlik kirjandus ja kirikulaulud. In: Altnurme, Riho (ed.). Eesti kiriku- ja religioonilugu. Õpik kórgkoolidele. Tartu: Tartu Ülikooli Kirjastus, 148-159.

Viiding, Kristi et al. (ed.) 2007. O Dorpat, urbs addictissima musis... Valik 17. sajandi Tartu juhuluulet. Tallinn: Eesti Keele Sihtasutus.

Viiding, Kristi; Lotman, Maria-Kristiina, Arukask, Anni; Kriisa, Kaidi; Truusalu, Tuuli Triin 2015. Ramus poeticus. Zur lateinischen Grabinschrift auf dem Sarkophag von Thomas Ramm in der Tallinner Domkirche. In: Baltic Journal of Art History $10,85-101$.

Viiding, Kristi 2019. The Humanist occasional Poetry in the Early Modern Estonia and Livonia. In: Jönsson, Arne; Lindgärde, Valborg, Möller, Daniel (eds.), Att dikta för livet, döden och evigheten Tillfällesdiktning 1500-1800. Lund. 